\title{
Front Matter: Volume 9004
}

, "Front Matter: Volume 9004," Proc. SPIE 9004, Emerging Liquid Crystal Technologies IX, 900401 (5 March 2014); doi: 10.1117/12.2063491

SPIE. Event: SPIE OPTO, 2014, San Francisco, California, United States 


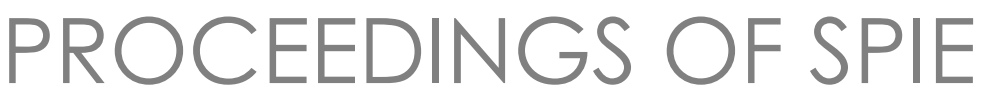

\title{
Emerging Liquid Crystal Technologies IX
}

\author{
Liang-Chy Chien \\ Antonio M. Figueiredo Neto \\ Kristiaan Neyts \\ Masanori Ozaki \\ Editors
}

5 February 2014

San Francisco, California, United States

Sponsored and Published by

SPIE 
The papers included in this volume were part of the technical conference cited on the cover and title page. Papers were selected and subject to review by the editors and conference program committee. Some conference presentations may not be available for publication. The papers published in these proceedings reflect the work and thoughts of the authors and are published herein as submitted. The publisher is not responsible for the validity of the information or for any outcomes resulting from reliance thereon.

Please use the following format to cite material from this book:

Author(s), "Title of Paper," in Emerging Liquid Crystal Technologies IX, edited by Liang-Chy Chien, Antonio M. Figueiredo Neto, Kristiaan Neyts, Masanori Ozaki, Proceedings of SPIE Vol. 9004 (SPIE, Bellingham, WA, 2014) Article CID Number.

ISSN: 0277-786X

ISBN: 9780819499172

\section{Published by}

\section{SPIE}

P.O. Box 10, Bellingham, Washington 98227-0010 USA

Telephone +1 3606763290 (Pacific Time) · Fax +1 3606471445

SPIE.org

Copyright @ 2014, Society of Photo-Optical Instrumentation Engineers.

Copying of material in this book for internal or personal use, or for the internal or personal use of specific clients, beyond the fair use provisions granted by the U.S. Copyright Law is authorized by SPIE subject to payment of copying fees. The Transactional Reporting Service base fee for this volume is $\$ 18.00$ per article (or portion thereof), which should be paid directly to the Copyright Clearance Center (CCC), 222 Rosewood Drive, Danvers, MA 01923. Payment may also be made electronically through CCC Online at copyright.com. Other copying for republication, resale, advertising or promotion, or any form of systematic or multiple reproduction of any material in this book is prohibited except with permission in writing from the publisher. The CCC fee code is 0277-786X/14/\$18.00.

Printed in the United States of America.

Publication of record for individual papers is online in the SPIE Digital Library.

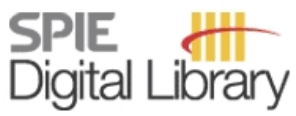

SPIEDigitalLibrary.org

Paper Numbering: Proceedings of SPIE follow an e-First publication model, with papers published first online and then in print and on CD-ROM. Papers are published as they are submitted and meet publication criteria. A unique, consistent, permanent citation identifier (CID) number is assigned to each article at the time of the first publication. Utilization of CIDs allows articles to be fully citable as soon as they are published online, and connects the same identifier to all online, print, and electronic versions of the publication. SPIE uses a six-digit CID article numbering system in which:

- The first four digits correspond to the SPIE volume number

- The last two digits indicate publication order within the volume using a Base 36 numbering

system employing both numerals and letters. These two-number sets start with 00, 01, 02, 03, 04, 05, 06, 07, 08, 09, 0A, 0B ... 0Z, followed by 10-1Z, 20-2Z, etc.

The CID Number appears on each page of the manuscript. The complete citation is used on the first page, and an abbreviated version on subsequent pages. Numbers in the index correspond to the last two digits of the six-digit CID Number. 


\section{Contents}

vii Conference Committee
ix Introduction

\section{SESSION 1 FLEXOELECTRIC, FERROELECTRIC, AND CHOLESTERIC MATERIALS}

900402 The past, present, and future of hockey-stick-shaped liquid crystals (Invited Paper) [9004-1]

E.-J. Choi, Kumoh National Institute of Technology (Korea, Republic of)

900404 Grayscale memory effect and flexoelectric property of highly kinked bent-core liquid crystals (Invited Paper) [9004-3]

J.-H. Lee, Chonbuk National Univ. (Korea, Republic of); T.-H. Yoon, Pusan National Univ. (Korea, Republic of); E.-J. Choi, Kumoh National Institute of Technology (Korea, Republic of)

\section{SESSION 2 LASING AND PHOTONIC MATERIALS}

$900406 \quad$ Twisting and tweezing liquid crystals with lasers (Invited Paper) [9004-5]

H. F. Gleeson, M. R. Dickinson, J. E. Sanders, Y. Yang, The Univ. of Manchester

(United Kingdom)

900407 Modeling optical modes of in-plane liquid crystal lasers (Invited Paper) [9004-6]

J. Beeckman, I. Nys, K. Neyts, Ghent Univ. (Belgium)

900408 Miscibility and phase separation in LC semiconductor blends (Invited Paper) [9004-7] Y. Shimizu, Y. Matsuda, National Institute of Advanced Industrial Science and Technology (Japan); T. Nakao, National Institute of Advanced Industrial Science and Technology (Japan) and Ryukoku Univ. (Japan); L. Sosa-Vargas, M. Takahashi, National Institute of Advanced Industrial Science and Technology (Japan); H. Yoshida, A. Fujii, M. Ozaki, Osaka Univ. (Japan)

\section{SESSION 3 PHOTOALIGNMENT, PHOTOPATTERNING, AND PHOTOTUNING}

9004 OA Liquid crystal devices based on photoalignment and photopatterning materials (Invited Paper) [9004-8]

V. Chigrinov, Hong Kong Univ. of Science and Technology (Hong Kong, China)

9004 OC Nematic colloidal tilings as photonic materials (Invited Paper) [9004-10]

M. Ravnik, Univ. of Ljubljana (Slovenia) and Ctr. of Excellence NAMASTE (Slovenia);

J. Dontabhaktuni, Univ. of Ljubljana (Slovenia) and Univ. Of Hyderabad (India); M. Cancula, Univ. of Ljubljana (Slovenia); S. Zumer, Univ. of Ljubljana (Slovenia), Ctr. of Excellence NAMASTE (Slovenia), and Jozef Stefan Institute (Slovenia) 
9004 OD In-situ calibration of spatial light modulators in femtosecond pulse shapers [9004-11]

B. Döpke, J. C. Balzer, M. R. Hofmann, Ruhr-Univ. Bochum (Germany)

\section{SESSION 4 DISPLAY AND HOLOGRAPHICALLY-FORMED MATERIALS}

9004 OF Long-pitch cholesteric liquid crystals for display applications (Invited Paper) [9004-12] T. -H. Yoon, J.-W. Huh, B.-H. Yu, Pusan National Univ. (Korea, Republic of)

$9004 \mathrm{OH} \quad$ Switchable liquid crystal contact lenses: dynamic vision for the ageing eye [9004-14] H. E. Milton, H. F. Gleeson, P. B. Morgan, The Univ. of Manchester (United Kingdom); J. W. Goodby, S. Cowling, The Univ. of York (United Kingdom); J. H. Clamp, UltraVision (United Kingdom)

$90040 \mathrm{~J} \quad$ Voltage controlled adaptive holographic interferometer using liquid crystals [9004-16] A. Peigné, Thales Underwater Systems (France) and Institut Non Linéaire de Nice Sophia Antipolis, CNRS, Univ. de Nice-Sophia Antipolis (France); U. Bortolozzo, S. Residori, Institut Non Linéaire de Nice Sophia Antipolis, CNRS, Univ. de Nice-Sophia Antipolis (France); S. Molin, D. Dolfi, Thales Research and Technology (France); J.-P. Huignard, Jphopto (France)

9004 OK Polarization-selective Bragg diffractive wavelengths in holographic structures composed of liquid crystal and polymer phases [9004-17]

H. Kakiuchida, K. Yoshimura, M. Tazawa, National Institute of Advanced Industrial Science and Technology (Japan); A. Ogiwara, Kobe City College of Technology (Japan)

POSTER SESSION

9004 OL Design of a cholesteric liquid crystal cell for a high-transmittance light shutter [9004-18] B.-H. Yu, J.-W. Huh, T.-H. Yoon, Pusan National Univ. (Korea, Republic of)

9004 OM Formation of holographic memory for optically reconfigurable gate array by anglemultiplexing recording of multi-circuit information in liquid crystal composites [9004-19] A. Ogiwara, H. Maekawa, Kobe City College of Technology (Japan); M. Watanabe, R. Moriwaki, Shizuoka Univ. (Japan)

900400 Fabrication of photo responsive multi-bilayered film consisting of azobenzene containing copolymers and polyvinyl alcohol [9004-21]

R. Yagi, Kumamoto Univ. (Japan); Y. Kuwahara, Kumamoto Univ. (Japan) and Kumamoto Institute for Photo-Electro Organics (Japan); H. Iwamoto, S.-N. Kim, T. Ogata, Kumamoto Univ. (Japan); S. Kurihara, Kumamoto Univ. (Japan), Kumamoto Institute for Photo-Electro Organics (Japan), and JST-CREST (Japan)

9004 OP Manipulation of small objects in liquid crystals by dynamical disorganizing effect of pushpull-azobenzene-dye [9004-22]

Y. Kuwahara, Kumamoto Univ. (Japan) and Kumamoto Institute for Photo-Electro Organics (Japan); T. Oda, R. Izumi, T. Ogata, S.-N. Kim, Kumamoto Univ. (Japan); S. Kurihara, Kumamoto Univ. (Japan), Kumamoto Institute for Photo-Electro Organics (Japan), and JST-CREST (Japan) 
$90040 Q \quad$ Thermo-driven light controller by using thermal modulation of diffraction wavelength in holographic polymer dispersed liquid crystal grating [9004-23]

A. Ogiwara, Kobe City College of Technology (Japan); H. Kakiuchida, National Institute of Advanced Industrial Science and Technology (Japan)

9004 OT Focused ion beam for studying cholesteric liquid crystals under submicrometer confinement [9004-29]

E. Enz, Martin-Luther-Univ. Halle-Wittenberg (Germany); V. La Ferrara, ENEA (Italy); G. Scalia, Advanced Institutes of Convergence Technology, Seoul National Univ. (Korea, Republic of)

9004 OU Molecular wires from discotic liquid crystals [9004-30]

J. H. Park, Seoul National Univ. (Korea, Republic of); M. Labardi, Istituto per i Processi Chimico Fisici, CNR (Italy) and Univ. di Pisa (Italy); G. Scalia, Advanced Institutes of Convergence Technology, Seoul National Univ. (Korea, Republic of)

9004 OV Effects of carbon nanotubes on a very low surfactant concentration lyotropic liquid crystal host [9004-31]

H. R. Jo, Seoul National Univ. (Korea, Republic of); J. Yamamoto, Kyoto Univ. (Japan); J. Lagerwall, G. Scalia, Advanced Institutes of Convergence Technology, Seoul National Univ. (Korea, Republic of)

Author Index 
Proc. of SPIE Vol. $9004900401-6$

Downloaded From: https://www.spiedigitallibrary.org/conference-proceedings-of-spie on 26 Apr 2023 Terms of Use: https://www.spiedigitallibrary.org/terms-of-use 


\section{Conference Committee}

Symposium Chairs

David L. Andrews, University of East Anglia Norwich (United Kingdom)

Alexei L. Glebov, OptiGrate Corporation (United States)

Symposium Co-chairs

Jean Emmanuel Broquin, IMEP-LAHC (France)

Shibin Jiang, AdValue Photonics, Inc. (United States)

Program Track Chair

Liang-Chy Chien, Kent State University (United States)

Conference Chair

Liang-Chy Chien, Kent State University (United States)

Conference Co-chairs

Antonio M. Figueiredo Neto, Universidade de São Paulo (Brazil)

Kristiaan Neyts, Universiteit Gent (Belgium)

Masanori Ozaki, Osaka University (Japan)

Conference Program Committee

Dick J. Broer, Technische Universiteit Eindhoven (Netherlands)

Vladimir G. Chigrinov, Hong Kong University of Science and

Technology (Hong Kong, China)

Harry J. Coles, University of Cambridge (United Kingdom)

Gregory Philip Crawford, University of Notre Dame (United States)

Andy Ying-Guey Fuh, National Cheng Kung University (Taiwan)

Wolfgang Haase, Technische Universität Darmstadt (Germany)

Jun-ichi Hanna, Tokyo Institute of Technology (Japan)

Hirotsugu Kikuchi, Kyushu University (Japan)

Heinz S. Kitzerow, Universität Paderborn (Germany)

Shunsuke Kobayashi, Tokyo University of Science (Japan)

Seung Hee Lee, Chonbuk National University (Korea, Republic of)

Yi-Hsin Lin, National Chiao Tung University (Taiwan)

Yan-Qing Lu, Nanjing University (China)

Ci-Ling Pan, National Tsing Hua University (Taiwan)

Ryo Sakurai, Bridgestone Corporation (Japan)

Ivan I. Smalyukh, University of Colorado at Boulder (United States) 
Richard L. Sutherland, Mount Vernon Nazarene University (United States)

Nelson V. Tabiryan, BEAM Engineering for Advanced Measurements Company (United States)

Ming Hsien Wu, Hamamatsu Corporation (United States)

Shin-Tson Wu, CREOL, The College of Optics and Photonics, University of Central Florida (United States)

Hiroshi Yokoyama, Kent State University (United States)

Tae-Hoon Yoon, Pusan National University (Korea, Republic of)

Yanlei Yu, Fudan University (China)

\section{Session Chairs}

1 Flexoelectric, Ferroelectric, and Cholesteric Materials

Helen F. Gleeson, The University of Manchester (United Kingdom)

2 Lasing and Photonic Materials

Miha Ravnik, University of Ljubljana (Slovenia)

3 Photoalignment, Photopatterning, and Phototuning

Tae-Hoon Yoon, Pusan National University (Korea, Republic of)

4 Display and Holographically-formed Materials

Vladimir G. Chigrinov, Hong Kong University of Science and Technology (Hong Kong, China) 


\title{
Introduction
}

As the world's leading conference of liquid crystal optics, photonics, and displays, the 2014 SPIE Photonics West "Emerging Liquid Crystal Technologies IX" conference successfully drew a large and enthusiastic crowd. The conference provided a venue for intellectual and enlightening discussions of the current state and exploration of emerging frontiers of liquid crystal science and technologies in optics, photonics and displays.

The scientific program covered a wide range of topics such as: blue phase materials, LC nanocomposites, liquid crystal metamaterials, optics of lyotropic systems, lasing in LCs, sensing, LCs in infrared optics, LC lenses, holographic and stereoscopic systems, 3D and new display applications, electronic books, and semiconductor/LC hybrid materials. The group of participants included a good number of invited speakers, junior scientists, and graduate students, who gave their research presentations at the conference. Student papers presented at both the oral and poster sessions drew large attendance and heavy traffic. We highly appreciate the program co-chairs and committee for their contributions, which are the foundation of this successful conference.

We look forward to seeing you at "Emerging Liquid Crystal Technologies X" conference in 2015.

\author{
Liang-Chy Chien \\ Antonio M. Figueiredo Neto \\ Kristiaan Neyts \\ Masanori Ozaki
}


Proc. of SPIE Vol. $9004900401-10$

Downloaded From: https://www.spiedigitallibrary.org/conference-proceedings-of-spie on 26 Apr 2023 Terms of Use: https://www.spiedigitallibrary.org/terms-of-use 